Revista de Estudios Histórico-Jurídicos

[Sección Historia del Derecho Europeo]

XXXIII (Valparaíso, Chile, 2011)

[pp. 375 - 398]

\title{
LA RECEPCIÓN DEL SENADOCONSULTO MACEDONIANO EN EL DEREChO ESPAÑOL ${ }^{*}$ \\ ["Reception of the Macedonian Senatus Consultum in the Spanish Law"]
}

\author{
Bernardo Periñán Gómez** \\ Universidad Pablo de Olavide, Sevilla
}

\section{RESUMEN}

La vigencia del sc. Macedoniano terminó con Roma, pero no puede decirse lo mismo de su influjo en la tradición jurídica occidental. En el Derecho histórico español puede reconocerse esa influencia a lo largo de su desarrollo, a pesar de los cambios en las relaciones familiares que llevan a la superación gradual del modelo romano de patria potestad. Es más, hoy día se puede percibir un resto del peso histórico de esta medida romana del siglo I d.C. en el artículo 323 del Código Civil.

Palabras clave

Hijos de familia - Emancipados Préstamo de dinero, - Senadoconsulto Macedoniano en el Derecho español.

\begin{abstract}
The validity of the Macedonian Senatus Consultum put an end to Rome. However, the same cannot be stated regarding its influx in the western juridical tradition. In the Spanish historical law, this influence can be recognized throughout its development, in spite of these changes in family relations, leading to gradually overcoming the Roman model of Parens Patriae. Furthermore, today we can perceive remnants of the historical weight of this Roman measure of the $1^{\text {st }}$ century A.D. in article 323 of the Civil Code.

\section{KeYwords}

Family children - emancipated - money loan - Macedonian Senatus Consultum in the Spanish Law.
\end{abstract}

RECiBIDO el 23 de marzo y ACEPTADO el 14 de julio de 2011

* La presente publicación se enmarca en el conjunto de actividades del Proyecto I+D MEC "Derecho, persona y ciudadano en la experiencia histórica y contemporánea" (SEJ200761825)

** Profesor titular en la Universidad Pablo de Olavide: , Sevilla, España. Dirección postal: Universidad Pablo de Olavide, Departamento de Derecho Privado, Carretera de Utrera, km. 1, 41013 Sevilla, España. Correo electrónico: bpergom@upo.es. 


\section{Planteamiento}

No escapa al estudioso del Derecho romano la práctica imposibilidad de que una regulación como la contenida en el senadoconsulto Macedoniano (sc. M., en adelante) sea recogida en el Derecho civil español, ya tomemos en consideración el Derecho histórico o el Derecho contemporáneo ${ }^{1}$. De hecho, nosotros también excluimos a priori el traslado de dicha medida vespasianea a nuestro ordenamiento civil, pues esta disposición senatorial presupone la existencia de la patria potestad romana, que, como es claro y tendremos ocasión de recalcar, no está recogida en toda su extensión en nuestro Derecho pasado, ni, por supuesto, en nuestro Derecho presente.

El objetivo de este estudio no es por tanto encontrar al sc. M. en el articulado del Código civil de hoy, ni en las Leyes civiles de ayer, sino descubrir reminiscencias, es decir, preceptos de Derecho patrio que recuerden al estudioso el aparente parecido con el "antecedente" romano, así como establecer las diferencias existentes entre este senatus consultum y sus posibles remembranzas ${ }^{2}$. Por otro lado, el análisis de las huellas de una regulación propia del Derecho romano, en este caso la derivada del sc. M., en el Derecho moderno, no puede interpretarse como el resultado de concebir a aquél en función de su presencia sustantiva en los ordenamientos subsiguientes, sino que debe entenderse como una aportación, desde el punto de vista romanístico, al Derecho histórico y al Derecho civil español ${ }^{3}$. Tratamos pues de arrojar luz sobre determinados preceptos de los sucesivos ordenamientos civiles españoles desde nuestra posición como romanistas, en la creencia de cumplir así una de las tareas que el estudioso del Derecho de Roma debe desempeñar ${ }^{4}$. Esta línea de investigación responde, además a una necesidad

${ }^{1}$ Sobre esta medida y su desarrollo jurisprudencial, puede verse: PERIÑÁn GómeZ, B., Antecedentes y consecuencias del sc. Macedoniano (Valencia, 2000). A dicha obra se remiten las alusiones al régimen del sc. M., evitando con esta alusión general la cita reiterada de la misma.

${ }^{2}$ El Diccionario de la lengua española de la $R A E$., atribuye al término reminiscencia los siguientes significados: 1 . Acción de representarse u ofrecerse a la memoria el recuerdo de una cosa que pasó. 2. Recuerdo vago e impreciso. 3. Fil. Facultad del alma con que traemos a la memoria aquellas imágenes de que estamos trascordados o que no tenemos presentes. 4 . En literatura y música, lo que es idéntico o muy semejante a lo compuesto anteriormente por otro autor. Por otra parte, el mismo lexicón se refiere al término senda, que empleamos en el título de este trabajo, como "Camino más estrecho que la vereda, abierto principalmente por el tránsito de peatones y del ganado menor”, es decir, somos conscientes de que la conexión del sc. M. y la realidad histórica y presente del Derecho es débil y sinuosa, en ocasiones difícil de reconocer entre la maleza.

${ }^{3}$ Sobre el empleo del Derecho romano como instrumento técnico para la crítica del Derecho positivo, con un estudio concreto acerca de la indignidad para suceder, véase: TORRENT RuIz, Armando, El Derecho romano como instrumento para la critica del Derecho positivo, en VV. AA., Homenaje a Juan Berchmans Vallet de Goytisolo (Madrid, 1988), I, pp. 753 ss.

${ }^{4}$ En admirables palabras de D'ORs, Álvaro, Escritos varios sobre el Derecho en crisis (Roma - Madrid, 1973), p. 14: "Ocurrió con el Derecho algo parecido a lo que podemos observar en los claustros románicos. Cuando los visitamos, no dejará de advertirnos el guía que nos acompaña cómo todos los capiteles son distintos. Indiscutiblemente, el artista quiso tener ese caprichoso lucimiento, pero los historiadores del arte saben muy bien que eso que acabó por 
sentida y manifestada por la doctrina con respecto al Derecho romano en general y a nuestra disposición senatorial en particular 5 .

\section{Análisis del Derecho histórico español}

Como hemos apuntado, al iniciar el estudio de la recepción del sc. M. en Derecho histórico español hemos de indagar si los principios de la patria potestas romana clásica, presupuesto necesario para la hipotética vigencia de una medida como la contenida en esta disposición senatorial, se mantienen en éste.

Ya en el Lib. Iudic. o Lex Visigothorum, máxima expresión de la legislación visigoda $^{6}$, encontramos, bajo la rúbrica: De his quae filii, patre vivente vel matre, videntur adquirere, un precepto que nos ofrece interesantes datos sobre el modelo de patria potestad que surge de esta nueva regulación de extendida implantación en los territorios peninsulares7. Dice el texto de Liber Iudiciorum, IV, 5,5: "Filius qui, patre vivente aut matre, aliquid adquisierit, sive de munificencia Regis, aut patronorum beneficiis promeruerit, et exinde aliquid cuicumque vendere, aut donare iuxta eam conditionem, quae in aliis nostris legibus continetur, in ipsius potestate consistat, nec sibi aliquid, dum filius vivit, exinde pater vel mater vindicare praesumant. Quod si inter leudes quicumque nec regiis beneficiis aliquid fuerit consequutus, sed in expeditionibus constitutus de labore suo aliquid aquisierit, si communis illi victus cum patre est, tertia pars exinde ad patrem perveniat, duas autem filius, qui laboravit, obtineat".

Este precepto nos muestra como ha habido ya un cambio importante con relación al Derecho romano, pues la norma declara la capacidad del hijo tanto para ser titular de los bienes que obtenga por donaciones del rey o del patrono, por su trabajo o en campaña, como para disponer de ellos incluso por donación. Tan sólo recoge la obligación que tiene el hijo que vive con su padre de entregar a éste la tercera parte de los bienes que tengan un origen distinto a la donación, pero estos bienes no los recibe el padre por ser declarado titular de los mismos, sino que más bien parecen una compensación para el ascendiente que tiene al

ser gala empezó en irremediable necesidad; la necesidad de aprovechar materiales dispersos incoherentes de viejos edificios romanos. [...], misión del romanista será la de interesarse por el Derecho moderno, pero, no tanto para explicarlo y no más, cuanto para depurarlo y superarlo."

${ }^{5}$ A. WACKE, La prohibición del crédito para los hijos de familia y el dictado de la razón económica, en Seminarios Complutenses de Derecho Romano, 6 (1994), pp. 179 y ss.; EL MISMO, Das Verbot der darlehnsgewährung an Hauskinder und die Gebote wirtschaflicher vernunft, en ZSS., 112 (1995), pp. 324 ss., estudia la presencia del sc. M. en el Derecho alemán, mientras que J. PARICIO, recensión a F. Lucrezi, Senatusconsultum Macedonianum (Napoli, 1992), en Ivra, 43 (1992), p. 222, echa de menos un estudio de este tipo en la obra que reseña.

${ }^{6}$ Para J. A. Alejandre García, Temas de Historia del Derecho: Derecho primitivo y romanización jurídica (Sevilla, 1981), p. 144, el Liber iudiciorum o Lex Visigothorum es la "obra cumbre de la legislación visigoda que supone la independencia total frente a la tradición romana” En el mismo sentido: E. Gacto Fernández - J. A. Alejandre García - J. M. García Marín, El Derecho histórico de los pueblos de España (5a edición, Madrid, 1985), pp. 137 ss.

${ }^{7}$ Sobre el establecimiento del Liber en la Alta Edad Media, véase: F. Tomás y Valiente, Manual de Historia del Derecho español (4a edición, Madrid, 1983), pp. 126 ss. 
hijo bajo su techo ${ }^{8}$. Se refiere, por tanto, a la situación patrimonial de los hijos declarando su independencia con respecto al patrimonio paterno, lo que supone una clara ruptura con respecto a la clásica patria potestas ${ }^{9}$.

Tras la caída del Reino visigodo de Toledo en el año 711 por efecto de la invasión musulmana y de las luchas dinásticas por la sucesión al trono cristiano, se desvanecen los intentos en pos de la unidad política peninsular. Esto, junto con otras circunstancias como las distintas repoblaciones ${ }^{10}$, provoca que el Derecho de la alta Edad Media se caracterice por el fraccionamiento jurídico que impera en la Península Ibérica tras la recuperación territorial por parte de los cristianos. De esta situación tenemos una muestra en la existencia de distintos Fueros ${ }^{11}$, ordenamientos particulares por razón del territorio que son clasificados por los historiadores del Derecho español, atendiendo a su amplitud y a la entidad del núcleo urbano al que corresponden, en Fueros breves y extensos ${ }^{12}$. Este último grupo se distingue además porque en estos Fueros se trata de regular todos los aspectos de la vida social y se recoge el Derecho consuetudinario preexistente, a diferencia de los Fueros breves que tienen su origen en la concesión de privilegios o franquicias.

El Fuero de Cuenca, "forensium institutionum summa"13, es uno de los más representativos de entre los extensos, por su altura técnica, por su amplio contenido y, sobre todo, por haber servido como modelo de otros muchos ordenamientos locales $^{14}$. Ante tales circunstancias, nos interesa saber qué tipo de patria potestad se

${ }^{8}$ Estos bienes de los que el hijo es propietario no tienen nada en común con el régimen del peculio romano, ya que el hijo es el único y exclusivo titular de los mismos, situación opuesta al régimen que tenía aquella parte del patrimonio paterno que se destinaba a que el hijo administrara separadamente. Véase: A. Otero Varela, La patria potestad en el Derecho histórico español, en AHDE., 26 (1956), p. 219.

${ }^{9}$ Acerca de la evolución general de la institución, Otero, ibíd., pp. 216 s., opina lo siguiente: "El Derecho visigodo recoge la idea de patria potestas tal y como se concebía después de aquella profunda transformación que hemos visto operarse en el Derecho romano [...]. Así, pues, de la misma manera que en el Derecho postclásico, la patria potestad de la legislación visigoda se concibe como un officium en interés de los hijos".

${ }^{10}$ Sobre la repoblación, véase: A. DE LA TORRE (editor), La reconquista española y la repoblación del país (Zaragoza, 1951); C. SÁNCHEZ-AlbORNOZ, España, un enigma histórico (8a edición, Barcelona 1981), II, pp. 33 ss.; F. Tomás y VAliente, Manual, cit. (n. 7), pp. 118 ss.

${ }^{11}$ F. Tomás y Valiente, Manual cit. (n. 7), p. 140: "Dejando al margen otras de sus acepciones, "fuero" significó norma jurídica singular; pero significó también el conjunto de normas, el ordenamiento jurídico vigente en un lugar determinado, esto es, su Derecho."

${ }^{12}$ A. García-Gallo, Manual de Historia del Derecho español, I: El origen y la evolución del Derecho (6a edición revisada, Madrid, 1975), pp. 378 ss.; J. LALINDE ABADía, Derecho histórico español (3a edición, Barcelona, 1983), p. 70; EL MISMO, Introducción histórica al Derecho español, (4a edición reformada, Barcelona, 1989), pp. 135 s.; F. Tomás y Valiente, Manual, cit. (n. 7), pp. 145 ss.; E. Gacto Fernández - J. A. Alejandre García - J. M. García Marín, El Derecho histórico, cit. (n. 6), pp. 196 ss.

${ }^{13}$ Así lo denominan sus propios redactores, véase: F. Tomás Y Valiente, Manual cit. (n. 7), p. 152.

${ }^{14}$ A. García-Gallo, Manual, cit. (n. 12), p. 384, entiende que el propio Fuero de Cuenca tuvo su base en un Formulario que, en torno al año 1200 y por iniciativa del rey Alfonso VIII, refunde otros ordenamientos locales de la Extremadura castellana. Acerca de la polémica en 
recoge en el mismo ${ }^{15}$, veamos un ejemplo tomado de Fuero de Cuenca, 206: "Filij sint in potestate parentum donec contrahant matrimonium, et sint filij familias. Et usque ad tempus illud, quicquid filij adquisierint, vel invenerint, totum sit parentum suorum, nec habeant potestatem sibi aliquid retinendi contra voluntatem eorum".

Este fragmento muestra, en opinión de Paulo Merêa ${ }^{16}$, un modelo de relaciones paterno-filiales observado en León y Castilla desde fines del siglo XII, cercano al vigente en Derecho romano y caracterizado por las siguientes notas: se habla de potestas parentum, como poder parental ostentado por el padre y la madre que cesaba con la muerte de cualquiera de los $\operatorname{dos}^{17}$; esta potestad la ejercen los progenitores sobre aquellos hijos que convivan bajo el techo familiar y tiene su manifestación más clara en que el filius no adquiere para sí sino para sus padres; por otra parte, éstos tenían la obligación de responder civilmente por los delitos cometidos por su hijo ${ }^{18}$.

Esta interpretación de las fuentes, aparentemente correcta, que permitiría reconocer un tipo de patria potestad similar al romano desde el punto de vista de sus efectos patrimoniales y que podría ser la base necesaria de una medida parecida al sc. M. no es, sin embargo, compartida por otros autores.

Para Otero Varela ${ }^{19}$, que niega principalmente la existencia de una potestad parental o conjunta de padre y madre, la familia de la Alta Edad Media se caracteriza en el aspecto patrimonial por ser la titular de una comunidad de bienes. Esto excluye que el hijo emparentado ${ }^{20}$ pueda ser considerado un filius familias desde el punto de vista romano ${ }^{21}$, pues adquiere, al igual que el resto de su familia, para la sociedad ${ }^{22}$.

torno a esta cuestión, véase: J. MARTíneZ Gijón, La familia del Fuero de Cuenca. Estado de una investigación cientifica, en Atti del II Congresso Internazionale della Società Italiana di Storia del Diritto (Firenze, 1971), pp. 415 ss.

${ }^{15}$ No hay datos suficientes en las fuentes sobre la patria potestad en el periodo que va desde la caída de la monarquía visigoda y los más tempranos Fueros extensos, como para hacernos una idea de su naturaleza. Según A. Otero Varela, La patria potestad, cit. (n. 8), pp. 223 s.: "Durante los primeros tiempos de la época posterior a la invasión musulmana debió continuar vigente la concepción visigoda de la patria potestad, pero es también lícito pensar que continuaría el proceso evolutivo de la institución, sumamente intenso desde la época clásica. [...]. Gayo no hubiera dudado en afirmar que en estos pueblos no existe la patria potestas".

${ }^{16}$ P. MERÊA, Notas sobre o poder paternal no Dereito hispânico ocidental, en Estudos de Dereito hispânico medieval (Coimbra, 1953), II, pp. 83 y ss., de donde citamos, originalmente publicado en $A H D E$., 18 (1947), pp. 15 ss.

${ }^{17}$ Sobre el origen de este poder parental, ibíd., pp. 98 ss.

${ }^{18}$ Fuero de Cuenca, 207: "Parentes itaque respondeant pro malefactis filiorum suorum, sive sint sani, sive furiosi [...]. Similiter, si filius orbatus fuerit altero parente, ille qui superstes fuerit, respondeat pro eo, donec det ei patrem subere, que eum contigerit. Post divisionem vero non habet utique responderé".

${ }^{19}$ A. Otero Varela, La patria potestad, cit. (n. 8), pp. 224 ss.

${ }^{20}$ Ibíd., p. 227: "Según la terminología de las fuentes, hijo emparentado es el que vivía con sus padres y forma parte de la comunidad familiar".

${ }^{21}$ Cfr. Fuero de Cuenca, 243.

${ }^{22}$ Las sociedades patrimoniales familiares, que pueden remontarse a los orígenes mismos de la familia patriarcal, respondían a las necesidades de la vida agraria. Acerca de estas comunidades y su plasmación práctica, confirmada en un completo estudio documental, véase: E. 
El Fuero Real, iniciativa de Alfonso X y promulgado en torno a 1255 con la finalidad de acabar con el fraccionamiento jurídico, es junto con el Espéculo la primera muestra de la recepción del Derecho romano en Castilla ${ }^{23}$. Sin embargo, con respecto al tema que nos ocupa, se recoge en él una tendencia, proveniente del Fuero de Soria ${ }^{24}$, que diferencia desde la base los nuevos principios de las relaciones paterno-filiales en el terreno patrimonial. Dicve FR. III,4,7: “Como los bienes que ganó el fijo estando en poder del padre, son suyos, si no los ganó con los bienes del padre. Si el fijo que está con su padre, è con su madre, ante que case ganare alguna cosa por su trabajo, ò que le dé el Rey, ò su Señor, ò otro home qualquier, no sea tenudo de dar parte à sus hermanos después de la muerte de su padre, ò de su madre, maguer gelo demande à parte, fueras si lo ganó con el haber del padre, ò de la madre, seyendo con el padre, ò con la madre: è gobernandose del haber del padre, ̀̀ de la madre: è maguer se gobierne de lo del padre, ò de la madre: si con el haber del padre, ò de la madre no lo ganáre, no sea tenudo de lo dar à partir: ca madre, ò padre siempre es tenudo de gobernar sus fijos: mas si con el haber del padre, è de la madre ganáre algo, estando en poder de amos, ò de algunos, el padre, ò la madre lo debe haber todo: y despues de su muerte del padre, ò de la madre, hayan la parte los hermanos".

Como puede verse, se reconoce al hijo la posibilidad de tener para sí determinados bienes: los que sean producto de su trabajo, si no los ganó con bienes del padre y los que le hayan sido donados ${ }^{25}$. Esto separa definitivamente, desde el punto de vista patrimonial, a la patria potestad en vigor del modelo romano.

Esta línea continúa con las Partidas, que datan del año 1265 aunque no recibieron fuerza de ley y su lugar en el sistema jurídico castellano hasta el "Ordenamiento de Alcalá" de 1348. La legislación alfonsina contempla y admite la independencia jurídica del hijo en el plano procesal ${ }^{26}$, además de recalcarla en el plano puramente patrimonial ${ }^{27}$. Este régimen se recoge en las Partidas, a pesar de que el Libro de las Leyes es considerado el vehículo de entrada del ius commune en Castilla y de que se hace eco de gran parte de los principios directores de la patria potestad justinianea ${ }^{28}$.

Montanos Ferrín, La familia en la Alta Edad Media española (Pamplona, 1980), pp. 161 ss. Este régimen patrimonial revela una raíz germánica y parece estar presente en nuestros días en la concepción aragonesa de la casa, en la sociedad familiar leonesa o en la compañía familiar gallega. Al respecto, véase: L. García DE VAldeAVEllano, La comunidad patrimonial de la familia en el Derecho español medieval (Salamanca, 1956); y RAMÓN P. RODRÍGUEz MONTERO, La "casa" en Galicia. Notas características y apuntes históricos sobre la regulación normativa de su indivisibilidad, en B. PERIÑÁN Gómez (coordinador), Derecho, persona y ciudadanía. Una experiencia juridica comparada (Madrid - Barcelona - Buenos Aires, 2010), pp. 369 ss.

${ }^{23}$ J. Paricio - A. Fernández Barreiro, Historia del Derecho romano y su Recepción europea, (2a edición, Madrid, 1997), p. 230.

${ }^{24}$ A. Otero Varela, La patria potestad, cit. (n. 8), p. 228.

${ }^{25}$ Una reforma del Fuero de Cuenca en este sentido fue llevada a cabo por medio de una mejora de Sancho IV en 1285. Cfr. Fuero de Cuenca, "Privilegio de Sancho", IV, 88-97.

${ }^{26}$ Cfr. Partidas III, 2,2.

${ }^{27}$ Cfr. Partidas VI,15,5.

${ }^{28}$ Cfr. Partidas VI, 17 y 18 , donde se recogen rasgos propios de la patria potestad romana tales como el poder perpetuo del padre sobre hijos y nietos, el Derecho de venta, diversos tipos de peculio, modos de emancipación o el usufructo paterno vitalicio sobre los bienes del filius. 
Por otra parte, al tratarse las Partidas de una legislación castellana, no puede hablarse de que este modelo justinianeo de patria potestas, aunque su recepción fuera más formal que sustancial, se extendiera al resto de los territorios peninsulares, en particular a los de la Corona de Aragón, que conserva su conformación medieval de relaciones familiares ${ }^{29}$. Sin embargo, puede decirse que con el tiempo y la uniformización del Derecho español, estará vigente el régimen de patria potestad derivado de las Partidas hasta la Ley de matrimonio civil de 1870, levemente modificado por las "Leyes de Toro" de $1505^{30}$.

Así las cosas, excluimos la posibilidad de un "calco" de nuestra disposición senatorial en el Derecho histórico español, puesto que desde sus inicios falta la principal razón de existir del régimen del senatus consultum Macedonianum, la patria potestas de corte romano clásico, la cual provoca una absoluta incapacidad al hijo de familia, para ser titular de derechos patrimoniales ${ }^{31}$; incapacidad que, además, define su status como alieni iuris.

Estas diferencias con el concepto romano de familia no se sitúan sólo en el ámbito patrimonial, sino que se encuentran en la base misma de la concepción de la institución. En palabras de Enma Montanos ${ }^{32}$ : "La familia medieval no tiene pues nada que ver en su estructura con la familia romana antigua tal y como aparece descrita en los manuales de Derecho romano, siendo la esencial diferencia entre una y otra el que, insistimos, así como en la romana lo esencial a la misma son los vínculos de naturaleza jurídica que aparecen uniendo a sus miembros, lo característico de la medieval es que su razón de ser tiene como principal y única característica la unión de sangre reinante entre sus miembros. [...] Se trata de una sociedad de naturaleza familiar en el sentido de agrupación de personas que en determinadas circunstancias van a aparecer actuando conjuntamente manteniendo dentro del grupo su propia individualidad y personalidad."

Encontramos en nuestro Derecho histórico, por tanto, una evolución hacia un nuevo concepto de persona. Esta condición no se identifica, como en el Derecho romano clásico, con el pater familias, sino que la atribución de personalidad jurídica a un individuo se separa totalmente de su posición familiar, si bien la familia no pierde todo su protagonismo desde el punto de vista patrimonial durante la alta Edad Media ${ }^{33}$.

Expresado todo lo anterior con toda la claridad de la que somos capaces, se constata que aparecen en nuestro Derecho histórico preceptos que nos recuerdan al senatus consultum Macedonianum.

Al respecto, véase: A. Otero Varela, La patria potestad, cit. (n. 8), p. 233, que entiende que estos principios sólo tuvieron un valor formal y que su anacronismo fue advertido incluso por los propios redactores de las Partidas.

${ }^{29}$ Véase: M. García Atance, "De consuetudine Regni non habemus patriam potestatem", en $A D A$., 6 (1951-1952), pp. 157 ss.

${ }^{30} \mathrm{Al}$ respecto véase: A. Otero Varela, La patria potestad, cit. (n. 8), pp. 232 ss.

${ }^{31}$ Cfr. D. 41,1,10,1 (Gai., 2 inst.).

${ }^{32}$ E. Montanos Ferrín, La familia cit. (n. 22), pp. 19 s.

${ }^{33}$ Ibíd., p. 161. Según J. LALINDE ABADÍA, Derecho histórico español, cit. (n. 12), p. 419: “El papel de la familia pierde importancia a partir de la Baja Edad Media a medida que el poder político la hace innecesaria y triunfa el individualismo innato en el hombre." 
Por ejemplo, en el Fuero de Cuenca, 208, desde el punto de vista de Otero Varela ${ }^{34}$, se incluye un pasaje que pudiera recordar a nuestra disposición senatorial. Exprtesa el texto: "Sed tamen parentes non respondeant pro hiis que acommodata, vel credita filiis fuerint suis".

Está claro, para nosotros, que el sentido de este fragmento es excluir la responsabilidad de los padres por todas las deudas del hijo que tuvieran un origen distinto al delictivo y que ni la capacidad del hijo para endeudarse, ni la integridad del negocio llevado a cabo por éste, sufren menoscabo alguno, ni en el plano sustantivo, ni en el procesal.

En Partidas V,1,4 y 6, se recogen los casos en que se permite que el hijo de familia $^{35}$ tome préstamos con todas las consecuencias, excluyendo consecuentemente que pudiera hacerlo en otros supuestos. El primer texto expresa: "Si demientra que estuuiere el fijo, o el nieto en poder del padre, o de su abuelo, tomare prestado de otro, sin mandato de aquel en cuyo poder está, non es tenudo el fijo, nin el padre, de tornar tal emprestamo; ni el fiador del fijo, maguer lo ouiesse dado: pero si el fijo tornase aquella misma cosa que le ouiesse emprestado, o otra tal que non fuesse de los bienes de su padre, o de su abuelo, valdra, si lo fiziere; e non gelo podria el padre vedar. Otrosi dezimos, que si el fijo, o el nieto, estando en poder de su padre, o de su abuelo, si a la sazon que tomasse la cosa emprestada, le preguntassen si auia padre, o abuelo, o alguno de los otros ascendientes, en cuyo poder estuuiesse, e lo negasse, diziendo que non; que por tal mentira que dixo, e nego la verdad, es tenudo de pechar aquello que tomo emprestado. Otrosi dezimos, que tuuiesse algund officio publicamente, del Rey, $o$ de otro Señor, o de algund Concejo; o que fuese menestral de qualquier menester, que vsasse a labrar publicamente; o tuuiesse tienda de cambio, o de paños, o de otra mercaduria, en que vsasse a labrar, e a mercar, bien assi como ome que no está en poder de otro; porque creen los omes, que este atal que estaua sobre si, es tenudo de pagar lo que tomare emprestado, maguer que este en poder de otro. Esso mismo dezimos, quando aquel que es en poder de otro. Es Cauallero; que si algo tomare emprestado, tenudo es de lo pagar. E esto es, porque non deue ome sospechar, que lo tomo prestado, que lo despendio en malos usos, maas en las cosas pertenecientes a Caualleria".

Podemos establecer similitudes y diferencias entre la regulación contenida en las Partidas y el sc. M..

La primera similitud es que ninguna de estas medidas prohibe el préstamo de dinero a los hijos de familia, pues - como hace el sc. M.- la norma de Derecho histórico se limita a descargar al hijo prestatario, a su padre y a su eventual fiador de la obligación de devolver lo prestado.

En segundo lugar, las Partidas reconocen excepciones a esta disposición que recuerdan en algunos casos a las derogaciones parciales que sufre el sc. M., como son la concurrencia del consentimiento paterno ${ }^{36}$ o la apariencia de quien es

${ }^{34}$ A. Otero Varela, La patria potestad, cit. (n. 8), p. 231.

${ }^{35}$ La condición de hijo de familia en nuestro Derecho histórico se aplica a quien estaba aún bajo la patria potestad o bajo el techo paterno, independientemente de la edad, pues la emancipación normalmente tenía lugar a través del matrimonio o la profesión religiosa. Véase: P. MerêA, Notas sobre o poder paternal, cit. (n. 16), pp. 88 ss.

${ }^{36}$ Cfr. D. 14,6,7,15 (Ulp., 29 ed.); 14,6,12 (Paul., 30 ed.); 14,6,14 (Iul., 12 dig). 
socialmente reconocido como persona no sometida a potestad ${ }^{37}$; la ley $6^{\text {a }}$ reconoce también la total exigibilidad del préstamo tomado por el hijo por razones de estudio ${ }^{38}$.

Otras excepciones a lo dispuesto en la ley $4^{\mathrm{a}}$ van en consonancia con la época, como la referente al hijo de familia Caballero. Entre las diferencias podemos también destacar la que separa el sc. M. y las Partidas en lo tocante a los distintos objetivos de una y otra disposición: mientras la medida romana se dirigía principalmente a proteger la patria potestad, la castellana se dirige, según entendemos, a proteger a los hijos de familia; éstos no tenían que ser menores necesariamente aunque lo serían en la mayoría de los casos, y eran protegidos contra su propia inexperiencia y frente a las malas costumbres, como se puede deducir tanto del texto, que habla, por ejemplo, del honroso fin de lo tomado en préstamo por el hijo de familia Caballero. Nótese de nuevo que ya no rige el modelo de patria potestad romana, a la que proteger, pues la misma ley $4^{a}$ permite que el hijo pague la deuda con sus propios bienes y por su voluntad, consentimiento que no puede ser vetado por el padre.

Hay que añadir además que la norma castellana prohíbe cualquier tipo de préstamo independientemente de su objeto, no sólo el mutuo ${ }^{39}$.

También en la Novísima Recopilación de 1805 aparecen, desde nuestra perspectiva, recuerdos del sc. M. Así en Nov. Rec. X,1,17 se recoge una disposición de Felipe II que coarta grandemente la capacidad negocial del hijo que está bajo la potestad de sus padres, medida que supone un paso atrás si lo comparamos con la libertad de disposición que sobre sus bienes, reconocía al hijo de familia el Liber Iudiciorum. El precitado texto señala: "No valgan los contratos y obligaciones que hicieren los hijos en poder de los padres, y los menores sin licencia de sus tutores. I D. Felipe II. en Valladolid año 1558 en las respuestas á los capitulos de Cortes de 555 pet. 78./ Mandamos, que agora ni de aqui adelante ningun hijo familias que esté debaxo del poder de sus padres, mayor ó menor, ni nigún menor que tenga tutor ó curador, sin licencia de los suso dichos no pueda comprar, ni tomar ni sacar en fiado por si ni otros en su nombre plata ni mercaderias, ni otro ningun género de cosas, ni ningun platero ni mercader, ni otra qualquier persona se lo pueda vender ni dar en fiado sin la dicha licencia: $y$ qualesquier contratos y fianzas, y seguridad y mancomunidad que sobre ello se ficieren y ordenaren con qualesquier cláusulas y firmezas en qualquier manera, todo sea ninguno, y por virtud dellos no se pueda pedir en juicio ni fuera dél en ningun tiempo cosa alguna á los dichos hijos familias ni menores, ni á sus fiadores ni principales pagadores, ni á otras qualesquier personas que por ellos se obligaren, $o$ en su nombre lo sacaren y tomaren, y sean libres de todo ello: y porque para defraudar lo de suso contenido, se procurará que los dichos contratos y fianzas se juren para su validacion, $y$ por ser contratos prohibidos por esta nuestra ley, $y$ disimulados y dolosos, $y$ fechos en grande daño y perjuicio de los dichos hijos familias y menores, mandamos á los dichos mercaderes y plateros, y otras qualesquier personas de suso declaradas, que

${ }^{37}$ Cfr. D. 14,6,3 pr. (Ulp., 29 ed.); 14,6,3,1 (Ulp., 29 ed.); 14,6,3,2 (Ulp., 29 ed.); 14,6,19

(Pomp., 7 var. lect.).

${ }^{38}$ Cfr. D. 14,6,7,13 (Ulp., 29 ed.); y Partidas V,1,6.

${ }^{39}$ Cfr. D. 14,6,3,3 (Ulp., 29 ed.). 
no fagan otorgar dichos contratos, ni atrayan a ninguna de las dichas personas á que los juren, ni los Escribanos den lugar á que ante ellos se otorguen ni juren, so pena que pierdan sus oficios, y no puedan mas usar de ellos de ahi en adelante; $y$ asimismo los dichos mercaderes y plateros, demas de perdimiento de sus oficios, incurran en pena de cien mil maravedis. [...]: y mandamos á todas las Justicias de nuestros reynos y señorios, compelan y executen todo lo suso dicho en nuestra ley contenido contra cada una de las personas, que contra lo en ella y en qualquier parte de ella contenido contraviniere".

La norma en examen, encuadrada bajo la rúbrica De los contratos y obligaciones, testamentos y herencias, poco tiene que ver con el sc. M, como a continuación explicamos:

Primero, provoca una amplia incapacidad para negociar al hijo de familia, mayor que la provocada por el sc. M., ya sea éste mayor o menor, prohibiéndole "comprar, ni tomar ni sacar en fiado por sí ni otros en su nombre plata ni mercaderias, ni otro ningun género de cosas”, sin el consentimiento de su padre.

Segundo, castiga estos negocios con la nulidad y consiguiente falta de exigibilidad ("todo sea ninguno, y por virtud dellos no se pueda pedir en juicio ni fuera dél en ningun tiempo cosa alguna [...], y sean libres de todo ello"); como sabemos, el sc. $\mathrm{M}$ no prohíbe nada, ni considera nulo el mutuo tomado por el hijo de familia.

Tercero, en este caso el consentimiento paterno no es una derogación parcial a la medida, sino el complemento necesario que la falta de capacidad del hijo requiere en estos negocios; el hijo es en esta norma equiparado al menor bajo tutela ${ }^{40}$. Este consentimiento se requiere también en el caso de la disposición anterior contenida en Nov. Rec. X,8,1, que permite exigir el préstamo concedido al estudiante sólo si para contraer la obligación contó con el consentimiento paterno ${ }^{41}$.

Y cuarto, claramente expresado está también en la letra de la Ley el objetivo de la misma ("por ser contratos prohibidos por esta nuestra ley [...] fechos en grande daño y perjuicio de los dichos hijos familias y menores"), que difiere abiertamente del que consideramos propio del sc. M.: la defensa de la patria potestas como institución. La finalidad protectora de la norma castellana, además de estar expresada en la misma, se detecta en la equiparación de ésta hace de hijo de familia y de los menores sometidos a tutela.

\footnotetext{
${ }^{40}$ Sobre la tutela en Derecho histórico español, véase: J. MARTínez Gijón, Los sistemas de tutela y administración de los bienes de los menores en el Derecho local de Navarra, en AHDE., 40 (1970), pp. 227 ss.; El MISMO, Los sistemas de tutela y administración de los bienes de los menores en el Derecho local de Castilla y León, en AHDE., 41 (1971), pp. 9 ss.; A. Merchán Álvarez, La tutela de los menores en Castilla hasta fines del siglo XV (Sevilla, 1976).

${ }^{41}$ Nov. Rec. X,8,1: "Prohibición de prestar y dar fiado á estudiante sin voluntad de su padre, $o ́$ de aquel que le tuviere en estudios. / D. Carlos y D. a Juana en Valladolid año 1542 pet. 6 y año 548 pet. 120/ Mandamos, que quando alguno prestare dineros, ó vendiere fiado á algún estudiante, estante en algún estudio, sin voluntad de su padre, ó del que allí le tiene á su costa, que no lo pueda pedir, ni tener recurso contra el padre o la madre, ni otra persona que lo hobiere alli enviado, ni los pueda citar sobre ello ante el Conservador del Estudio, ni ante otra Justicia alguna, sino á la misma parte".
} 


\section{AnÁlisis Del Derecho CIVIL ESPAÑol}

Antes de examinar nuestro ordenamiento civil vigente, hemos de tener presente que los principios directores del mismo en el ámbito que nos ocupa, son muy diferentes a aquéllos propios del Derecho romano y del Derecho histórico español; nos encontramos, en primer lugar, con un nuevo concepto de persona en el que no inciden las circunstancias familiares, surgido de las ideas del iusnaturalismo racionalista, que inspira la codificación civil francesa, y con un nuevo concepto de patria potestad, circunscrita al periodo en que el individuo es menor de edad y sometida a control jurisdiccional.

Por otra parte, se ha producido un importante cambio en la sociedad que modifica el prototipo de familia con que se encuentra el Derecho; se ha pasado de una familia troncal y autárquica, con vocación de estabilidad y propia de una economía agraria, a una familia nuclear, con un reducido número de miembros, inestable en cuanto tiende a descomponerse en otras entidades familiares en cuanto los hijos están en condiciones de construir una vida independiente, como corresponde a una sociedad industrial y liberal.

Si hemos excluido la presencia de un modelo de patria potestad de corte romano en nuestro Derecho histórico, poco sentido tendría plantearse la búsqueda de rasgos romanos en las relaciones paterno-filiales de hoy, como condición previa necesaria de una medida como el sc. M. No en vano, los principios que inspiran nuestro ordenamiento jurídico impiden que una patria potestas como la romana pueda encontrarse en nuestro ordenamiento, que concibe el poder paternal en beneficio de los hijos ${ }^{42}$.

Esta línea favorecedora del hijo de familia en cuanto es menor, pues la mayoría de edad implica la salida de la patria potestad ${ }^{43}$, se refuerza con la última regulación

${ }^{42}$ La CPolEsp., dice en su artículo 39, 30: "Los padres deben prestar asistencia de todo orden a los hijos habidos dentro y fuera del matrimonio, durante su minoría de edad y en los demás casos en que legalmente proceda." Por otra parte, en el Fuero de los Españoles de 1945, artículo 23, ya se recogía la obligación de los padres de alimentar, educar e instruir a sus hijos sin perjuicio de las facultades del Estado, para suspender o privar del ejercicio de la patria potestad a quienes no la ejerzan dignamente.

${ }^{43}$ Así consta ya en la Ley de matrimonio civil de 18 de junio de 1870 y se mantiene en el artículo 314, 1. ${ }^{\circ}$ CCEsp. La mayoría de edad ha recibido en nuestro Derecho varias regulaciones. En la redacción inicial del Código se fija el límite en los veintitrés años, cfr. artículo 320, si bien en Cataluña y Navarra se eleva hasta los veinticinco por aplicación del Derecho romano, cfr. D. 4,4,2 (Ulp., 11 ed.) y la sentencia del Tribunal Supremo. de 1 de abril de 1891; mientras que en Aragón queda reducido a la edad de veinte años. Esta situación se mantiene hasta la Ley de 13 de diciembre de 1943, año en que la mayoría de edad se fija para todos los españoles en ventiún años cumplidos, si bien esta reforma no se trasladó al Código hasta la Ley $\mathrm{N}^{\circ} 31 / 1972$, de 22 de julio, de la Jefatura del Estado, sobre modificación de los artículos 320 y 321 del Código Civily derogación del número 3 del artículo 1880 y de los artículos 1901 a

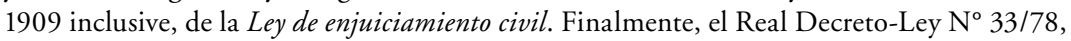
de 16 de noviembre, reduce a dieciocho años la edad establecida para alcanzar la mayoría de edad en todo el territorio nacional; la fijación de la mayoría de edad en los dieciocho años ha sobrepasado el ámbito puramente civil, pues es recogida en el artículo 12 C.E.. Acerca del 
sobre el menor de edad, al que se considera objeto de especial amparo ${ }^{44}$.

Por otra parte, el resultado de la aplicación de los nuevos principios jurídicoconstitucionales, cuya configuración histórica arranca de la Declaración de los Derechos del Hombre y del Ciudadano de $1789^{45}$, en nuestro Derecho civil hace surgir en este ordenamiento un nuevo concepto de persona, muy distinto al romano que identificaba al pater familias con el único posible sujeto de Derecho. Así, la Ley de matrimonio civil de 18 de junio 1870, ejemplo de la tendencia a regular a través de leyes especiales determinadas materias que se contendrían en el futuro Código Civil ${ }^{46}$, provocó considerables modificaciones en la regulación de la patria potestad, aunque seguía teniendo base justinianea ${ }^{47}$. Por ejemplo, en su artículo 64 recoge una potestad subsidiaria de la madre en defecto del padre y consagra la emancipación por mayoría de $\operatorname{edad}^{48}$, pero se mantiene aún la idea de concebir como un Derecho el que los hijos legítimos no emancipados vivan en su compañía y se admite un moderado ius puniendi sobre éstos ${ }^{49}$.

Desde el punto de vista patrimonial, es llamativa la desaparición de los pecu$\operatorname{lios}^{50}$, pero se atribuye a los padres la propiedad de los bienes adquiridos por el hijo por cualquier actividad, siempre que los obtuviera con el caudal puesto a su

significado de este precepto constitucional véase: E. Ramos Chaparro, Niños y jóvenes en el Derecho civil constitucional, en DPC., 7 (1995), pp. 167 ss.

${ }^{44}$ Ley Orgánica $\mathrm{N}^{\circ} 1 / 1996$, de 15 de enero, de Protección jurídica del menor, de modificación parcial del Código Civil y de la Ley de Enjuiciamiento Civil. Cfr. la "Disposición derogatoria única” de la citada Ley orgánica, a aquélla esencialmente administrativa que se contenía en el Texto refundido de la legislación sobre protección de menores, aprobado por Decreto de 2 de julio de 1948. Sobre las perspectivas futuras en este ámbito, puede verse: C. Villagrasa AlCAide, Nuevos retos legislativos en los derechos de la infancia y la adolescencia, en B. Periñán GómeZ (coordinador), Derecho, persona y ciudadania, cit. (n. 22), pp. 543 ss.

${ }^{45}$ Artículo 1: "Les hommes naissent et demeurent libres et égaux en droits. Les distinctions sociales ne peuvent êrte fondées que sur l'utilité commune". Esta Déclaration de la Asamblea francesa, de clara inspiración iusnaturalista, tuvo su antecedente en la Declaración de Derechos (Bill of Rights) del Buen Pueblo de Virginia de 1776, donde se lee: "Todos los hombres son por naturaleza igualmente libres y tienen ciertos derechos innatos, de los que, cuando entran en estado de sociedad, no pueden privar o desposeer a su posteridad por ningún pacto, a saber: el goce de la vida y de la libertad, con los medios de adquirir y poseer la propiedad y de buscar y obtener la felicidad y la seguridad".

${ }^{46}$ Esta ley especial por razón de la materia que regulaba, estuvo en vigor sólo hasta poco después de la Restauración borbónica, pues fue derogada por Decreto de 9 de febrero de 1875 por motivo de su acusado carácter laicista. Acerca de su incidencia en la sociedad española de la época, véase: L. DíEz-PICAZo, El Derecho de la persona y el Derecho de familia en la Legislación de 1870, en Estudios de Derecho privado (Madrid 1980), pp. 17 ss.

${ }^{47}$ Véase: A. Otero Varela, La patria potestad, cit. (n. 8), p. 240.

${ }^{48}$ Ley de matrimonio civil de 18 de junio de 1870, artículo 64: "El padre, y en su defecto la madre, tienen potestad sobre sus hijos legitimos no emancipados. Se reputará emancipado de Derecho al hijo legitimo desde que hubiere entrado en la mayor edad".

${ }^{49}$ Ley de matrimonio civil de 18 de junio de 1870, artículo 65: "En consecuencia de tal potestad, el padre y en su defecto la madre tendrán Derecho: 1. $A$ que sus hijos legitimos no emancipados vivan en su compañia, y a representarlos en juicio en todos los actos jurídicos que le sean favorables. $2 .^{\circ} \mathrm{A}$ corregirlos y castigarlos moderadamente. [...]".

${ }^{50}$ Los peculios sí están presentes en el Proyecto de Código Civil de 1851, cfr. artículos 151, 152,153 y 154 . 
disposición por los progenitores. En cambio, sobre el resto de las adquisiciones del hijo los padres sólo tendrán un Derecho de administración y usufructo ${ }^{51}$, con algunas limitaciones en favor de la conservación de ese patrimonio ${ }^{52}$. Estos derechos sólo se reconocen a los padres en el caso de que el hijo viva en su compañía ${ }^{53}$, en caso contrario el hijo es tenido por emancipado y se le considera hábil para la administración y usufructo de dichos bienes ${ }^{54}$.

Una muestra de la evolución de la legislación hacia la protección de los intereses de los hijos la tenemos en el artículo 68 de la misma ley, del cual encontramos un claro precedente en la legislación justinianea ${ }^{55}$, en el que se excluyen de un posible Derecho de propiedad o usufructo a favor de los padres sobre los bienes donados al hijo para su educación ${ }^{56}$.

Visto lo anterior y teniendo en cuenta la futura regulación codificada, no deja de ser curiosa, por exagerada, la interpretación jurisprudencial sobre la naturaleza de las relaciones paterno-filiales que se hace en la sentencia del Tribunal Supremo de 20 de marzo de 1889. Dicha sentencia se sitúa en "terreno de nadie" desde el punto de vista legislativo, pues es anterior al Código Civil y posterior a la derogación de la Ley de matrimonio civil, y en ella se considera que los contratos celebrados entre padres e hijos son nulos, ya que se estima la existencia de una sola personalidad ${ }^{57}$. Probablemente, esta resolución refleja el pensamiento de unos jueces que, producto de su tiempo, no asimilaron un modelo jurídico distinto del modelo social que realmente se imponía por la fuerza de los hechos. En otras palabras, el viejo esquema romano de relaciones paterno-filiales salía entonces a la superficie y cobraba relevancia jurídica en ausencia de una norma

${ }^{51}$ Ley de matrimonio civil de 18 de junio de 1870, artículo 65: "En consecuencia de tal potestad, el padre y en su defecto la madre tendrán Derecho: [...]. 3.' A hacer suyos los bienes que adquieren con el caudal que hubieren aquéllos puesto a su disposición para cualquier industria, comercio o lucro. $4 .^{\circ} \mathrm{A}$ administrar y usufructuar los bienes que los hijos hubieren adquirido por cualquier titulo lucrativo o por su trabajo o industria".

${ }^{52}$ Ley de matrimonio civil de 18 de junio de 1870, artículo 69: "El padre, y en su defecto la madre, cuando gocen del usufructo de los bienes de los hijos, tendrán las obligaciones de todo usufructuario, excepto la de afianzar respecto de los mismos bienes, mientras no contrajeren segundas nupcias. También estarán obligados a formar inventario, con intervención del ministerio fiscal, de los bienes de los hijos respecto de los cuales tuvieren solamente la administración".

${ }^{53}$ Ley de matrimonio civil de 18 de junio de 1870, artículo 66: "El padre, y en su defecto la madre, no adquirirán la propiedad, el usufructo ni administración de los bienes adquiridos por el hijo con su trabajo o industria, si no viviere en su compañia".

${ }^{54}$ Ley de matrimonio civil de 18 de junio de 1870, artículo 67: "El hijo se reputará como emancipado para la administración y usufructo de los bienes comprendidos en el artículo anterior".

${ }^{55}$ Cfr. Nov. 117,1.

${ }^{56}$ Ley de matrimonio civil de 18 de junio de 1870, artículo 68: "Tampoco adquirirá el padre, y en su defecto la madre, la propiedad ni el usufructo de los bienes donados o mandados al hijo para los gastos de su educación e instrucción, o con la condición expresa de que aquéllos no hubieran de usufructuarlos, si en este caso los bienes donados no constituyen la legitima del hijo".

${ }^{57}$ Véase: S. Coderch Manau - S. Coderch Mir, Tratado de la menor edad. Estudio de la situación legal del menor mientras está sujeto a patria potestad y a tutela, cuando ha obtenido su emancipación y al llegar a la mayor edad, asi como de los derechos y deberes de sus padres, de su Consejo de familia, de su tutor y de su protutor (Barcelona 1917), p. 19. 
que lo modificara, a pesar de los casi treinta años de vigencia que había tenido la Ley de matrimonio civil.

Empero, el Código Civil de 1889, como no podía ser de otra manera, avanza paulatinamente por el camino que se aleja del modelo romano de patria potestas.

En su redacción original el Código reconoce, del mismo modo que en la legislación anterior, una patria potestad preferentemente paterna, que da a la madre un papel subsidiario, sobre sus hijos legítimos no emancipados, así como sobre sus hijos naturales reconocidos y los adoptivos ${ }^{58}$. Como consecuencia de esta potestad, las acciones provechosas para los hijos han de ejercitarse por el padre en representación de éstos ${ }^{59}$. Frente al Derecho de los padres de corregir y castigar moderadamente a sus hijos ${ }^{60}$, se atribuye a éstos el Derecho a ser alimentados, a vivir en compañía de sus padres y a recibir de ellos educación e instrucción con arreglo a su fortuna ${ }^{61}$, obligación paterna sancionada también en el ámbito penal ${ }^{62}$.

En el ámbito patrimonial, nuestro Código Civil de 1889 consideraba al padre $y$, en defecto de éste, a la madre, administradores legales de los bienes del hijo ${ }^{63}$, si bien a este Derecho de administración se le añade el Derecho de usufructo sobre determinadas partes de ese patrimonio y, en ocasiones el Derecho de propiedad. Por tal motivo los bienes del hijo pueden ser de tres clases ${ }^{64}$ : aquéllos sobre los que los padres sólo tienen la administración ${ }^{65}$, bienes propiedad del hijo de los que los padres son considerados administradores y usufructuarios ${ }^{66}$ y bienes sobre los que los padres son considerados propietarios de los mismos ${ }^{67}$.

Por último, destacamos que junto a los acontecimientos que ponen fin de la

${ }^{58}$ Cfr. artículo 154 CCEsp.

${ }^{59}$ Cfr. artículo 155 CCEsp.

${ }^{60}$ Los padres pueden incluso reclamar la intervención del Juez municipal para que el hijo sea internado en un establecimiento correccional, por un periodo no superior a un mes, cfr. artículo 156 CCEsp. Hay mayores garantías con respecto a esta facultad paterna, para evitar posibles abusos, en los casos en que el padre o la madre hubiera contraído segundas nupcias y el hijo fuera del primer matrimonio; asimismo, se requiere que la petición paterna sea motivada y que el hijo comparezca ante el Juez, si aquél ejerce algún oficio, cfr. artículo 159 CCE .

${ }^{61}$ Cfr. artículo 155 CCEsp.

${ }^{62}$ Cfr. artículo 603, $\mathrm{N}^{\circ} 5$ del Código Penal de 1870.

${ }^{63}$ Cfr. artículo 159 CCEsp.

${ }^{64}$ Véase: S. Coderch Manau - S. Coderch Mir, Tratado de la menor edad, cit. (n. 57), p. 28. Sobre el régimen de la preceptiva autorización para determinados actos de disposición especialmente graves y acerca de los supuestos en que debe nombrarse un defensor judicial, ibíd., pp. 34 ss.

${ }^{65}$ Bienes donados o legados a los hijos para su educación o instrucción, siempre que el donante no hubiera dispuesto otro administrador. Cfr. artículo 162 CCEsp.

${ }^{66}$ Aquéllos que el hijo adquiera con su trabajo, industria o por cualquier título lucrativo, salvo si el hijo tuviese vida independiente de sus padres con consentimiento de éstos, ya que en este caso se le reputará como emancipado. Cfr. art 160 CCEsp.

${ }^{67}$ Éstos serían los bienes obtenidos por el hijo con el patrimonio paterno, que si fueran cedidos a aquél en todo o en parte no serían computados en la futura herencia. Cfr. artículo 161 CCEsp. Para E. Llamas Pombo, El patrimonio de los hijos sometidos a la patria potestad (Madrid, 1993), pp. 28 s., estos bienes representan un residuo del peculio profecticio adaptado a las circunstancias de finales del siglo XIX. 
patria potestad ${ }^{68}$, se recogían en la primera redacción del Código Civil casos de pérdida $^{69}$, suspensión ${ }^{70}$ y privación de la patria potestas ${ }^{71}$, sin que ésta última libere al padre o a la madre del deber de alimentar a los hijos ${ }^{72}$.

A raíz de la Ley $\mathrm{N}^{\circ}$ 11/1981, de 13 de mayo, de modificación del Código Civil en materia de filiación, patria potestad y régimen económico del matrimonio, se produjeron en la regulación de la patria potestad, una serie de innovaciones entre las que destacamos las siguientes ${ }^{73}$ :

Se admite el ejercicio conjunto de la patria potestad por el padre y la madre ${ }^{74}$, sobre todos los hijos no emancipados independientemente de su tipo de filiación ${ }^{75}$ y se permite a los hijos investigar sobre la paternidad o la maternidad ${ }^{76}$.

La patria potestad ha de ejercerse "siempre en beneficio de los hijos y de acuerdo con su personalidad"77, incluyendo la posibilidad de que un cónyuge asuma su

${ }^{68}$ Muerte de los padres o del hijo, emancipación, adopción del hijo, cfr. artículo 167 CCEsp., o pasar la madre a segundas nupcias, cfr. artículo 168 CCEsp.

${ }^{69} \mathrm{Cfr}$. artículo 169 CCEsp.

${ }^{70} \mathrm{Cfr}$. artículo 170 CCEsp.

${ }^{71}$ Cfr. artículo 171 CCEsp.

${ }^{72}$ Sentencia del Tribunal Supremo de 23 de junio de 1905.

${ }^{73}$ No se producen alteraciones de consideración en la regulación de la patria potestad, con respecto a lo que a nosotros nos interesa, a través de la Ley de 24 de abril de 1958, por la que se modifican determinados artículos del Código Civil, ni a raíz de la Ley n 22/1978, de 26 de mayo, de despenalización del adulterio y amancebamiento, derogaciones y modificaciones del Código Civil.

${ }^{74}$ Esta innovación deriva directamente la CPolEsp., que en su artículo 14 dice: "Los españoles son iguales ante la ley, sin que pueda prevalecer discriminación alguna por razón de nacimiento, raza, sexo, religión, opinión o cualquier otra condición o circunstancia personal o social". Mientras que el artículo 32, $\mathrm{N}^{\circ} 1$ CPolEsp., recoge la igualdad en el ámbito matrimonial: "El hombre y la mujer tienen Derecho a contraer matrimonio con plena igualdad jurídica".

${ }^{75}$ Cfr. artículo 156 CCEsp. Según J. López Pérez, La patria potestad: Voluntad del titular ("Prólogo" de I. Serrano y Serrano, Valladolid 1982), p. 52 s.: "Con ello se viene a incorporar de modo definitivo a nuestro Derecho, ese ejercicio conjunto de la patria potestad, con la supresión de los recuerdos arcaicos y particularmente romanos que ofrecía la anterior redacción." Un anticipo de esta reforma se encuentra en la Ley $\mathrm{N}^{\circ}$ 14/1975, de 2 de mayo, de la Jefatura del Estado, sobre la reforma de determinados artículos del Código Civil y del Código de Comercio sobre la situación jurídica de la mujer casada y los derechos y deberes de los cónyuges, que modifica el artículo 58 CCEsp., de modo que el lugar de residencia de la familia había de fijarse de modo conjunto por el padre y por la madre.

${ }^{76} \mathrm{Cfr}$. artículo 127 CCEsp., cuyo contenido está de acuerdo con lo establecido en el artículo 39, $\mathrm{N}^{\circ} 2$ CPolEsp. Este artículo ha sido derogado por la Ley $\mathrm{N}^{\circ} 1 / 2000$, de enjuiciamiento civil, en la que se recogen ahora el régimen de estas acciones de modo similar a como lo hacía el Código Civil.

${ }^{77}$ Cfr. artículo 154 CCEsp. Esta característica de la moderna patria potestad sobresale por encima de otras presentes en su actual configuración, como ser una institución de orden público y estar fuera del comercio. Véase: J. López Pérez, La patria potestad cit. (n. 75), p. 35. Este precepto ha sido reformado por la Ley $\mathrm{N}^{\circ}$ 54/2007, de Adopción Internacional. En su redacción actual, el párrafo aludido queda redactado del modo siguiente: "La patria potestad se ejercerá siempre en beneficio de los hijos, de acuerdo con su personalidad, y con respeto a su integridad fisica y psicológica". Nótese el añadido final que refuerza el deber paterno de ejercer la potestad paterna con consideración a la personalidad separada del hijo. 
ejercicio de acuerdo con el consentimiento expreso del otro ${ }^{78}$.

En el ámbito patrimonial, destaca el usufructo paterno sobre los bienes propiedad del hijo, sea cual sea su origen ${ }^{79}$, si bien esta privación a los padres se compensa con la obligación del descendiente de contribuir al sostenimiento de las cargas familiares ${ }^{80}$. Los padres, empero, ostentan la administración de los bienes del hijo ${ }^{81}$, labor que está sometida a una serie de controles en favor de éste ${ }^{82}$, y la representación legal de los menores no emancipados, función sujeta a unas de limitaciones que afectan principalmente a los derechos de la personalidad y a supuestos en que pudiera darse un conflicto de intereses ${ }^{83}$.

En beneficio del incapaz se recoge la posible prórroga de la patria potestad, que aun siendo la misma sufrirá algunas modificaciones por lo que respecta a la administración de los bienes del hijo incapaz, evitando así la entrada en juego de las instituciones tutelares ${ }^{84}$. Por otra parte, es notoria -como innovación de esta reforma legislativa- el refuerzo de los controles públicos sobre el ejercicio de la patria potestad ${ }^{85}$.

La siguiente reforma de calado del Código Civil en materia de patria potestad deriva de la Ley Orgánica 1/1996, de 15 de enero, de Protección jurídica del menor ${ }^{86}$.

${ }^{78} \mathrm{Cfr}$. artículo 156 CCEsp. Esta última innovación legislativa es objeto de crítica en cuanto no casa adecuadamente con el carácter esencialmente protector que recibe la patria potestad en esta regulación, véase: J. López Pérez, La patria potestad cit. (n. 75), p. 17.

${ }^{79}$ Cfr. artículo 165, I CPolEsp.

${ }^{80} \mathrm{Cfr}$. los artículos. $155 \mathrm{~N}^{\circ} 2$ y 165 CCEsp. En general, sobre los aspectos patrimoniales derivados de esta reforma, puede verse: A. VENTOSO ESCRIBANO, La representación y disposición de los bines de los hijos (Madrid, 1989); M. A. Linacero De La Fuente, Régimen patrimonial de la patria potestad (Madrid, 1990).

${ }^{81}$ En palabras de E. Llamas POMBo, El patrimonio de los hijos cit. (n. 67), p. 34. "Se borran los vestigios de la doctrina romana de los peculios, que [...] perduraban en el Código Civil. Asíse da por supuesto que el hijo es titular de todos los bienes y derechos que adquiere, pues su única incapacidad se refiere al ejercicio de tales derechos, pero no a su capacidad dispositiva".

${ }^{82}$ Cfr. los artículos 158 (ahora reformado por la Ley Orgánica $N^{\circ} 1 / 1996$, de Protección jurídica del menor), 164 (reformado por la Ley No 21/1987, de Reforma del Código civily de la Ley de Enjuiciamiento Civil, y por la Ley $\mathrm{N}^{\circ} 13 / 2005$, por la que se modifica el Código civil en materia de Derecho a contraer matrimonio), 166 (reformado por la Ley Orgánica N 1/1996, de Protección jurídica del menor), 167 y 168 CCEsp.

${ }^{83} \mathrm{Cfr}$. artículo 162 CCEsp.

${ }^{84} \mathrm{Cfr}$. artículo 171 CCEsp. (reformado por la Ley $\mathrm{N}^{\circ}$ 13/1983, de reforma del Código Civil en materia de tutela, y por la Ley Orgánica $\mathrm{N}^{\circ} 1 / 1996$, de Protección Jurídica del menor)

${ }^{85} \mathrm{Al}$ respecto, véase: L. DízZ-PICAZO, Notas sobre la reforma del Código civil en materia de patria potestad, en Anuario de Derecho Civil, 25 (1982) 1, pp. 6 ss.. Entre otras medidas destacamos la intervención judicial recogida en el artículo 156 CCEsp y la previsión del nombramiento de un defensor judicial para el hijo en los casos recogidos en el artículo 163 CCEsp.

${ }^{86}$ Acerca de los instrumentos internacionales para la protección del menor y de los precedentes de la legislación española reciente en este sentido, véase la Ley Orgánica $N^{\circ} 1 / 1996$, "Exposición de Motivos", $\$ 1$. Por otra parte, a raíz de esta Ley se tomaron hasta ahora en las distintas Comunidades Autónomas con competencias en la materia, medidas encaminadas a lograr la protección de los menores, véase: M. Rivera FernándeZ, Anotaciones a la Ley 1/1996, de 15 de enero, de protección jurídica al menor, en RGD., 621 (junio 1996), p. 6502, n. 3. Cfr. la "Disposición final vigésima primera", que en su parte no orgánica es de aplicación subsidiaria 
Desde nuestro punto de vista, esta Ley Orgánica que de modo genérico, entiende que el interés superior de los menores ha de presidir la aplicación de la misma "sobre cualquier otro interés legítimo" ${ }^{87}$, incidió en las relaciones paterno-filiales en un triple sentido: primero, es clara la voluntad de la ley de que las limitaciones a la capacidad de obrar de los menores sean interpretadas de modo restrictivo ${ }^{88}$, sin que este mandato legal pueda traducirse como una voluntad de considerar al menor plenamente capaz ${ }^{89}$; segundo, es notoria la influencia del artículo 9 de la citada Ley orgánica, en el que se recoge el Derecho del menor "a ser oído [...] en cualquier procedimiento administrativo o judicial en que esté implicado y que conduzca a una decisión que afecte a sus esfera personal, familiar o social', lo que acarrea un mayor protagonismo del menor en el ámbito procesal, de acuerdo con su capacidad natural, sin excluir la representación de los padres $^{90}$; y tercero, se incrementan los controles públicos sobre el ejercicio de la potestad paternal ${ }^{91}$.

Como consecuencia del nuevo marco constitucional y civil se presenta ante nosotros un nuevo concepto de personalidad que no coincide en absoluto con el modelo romano clásico que, como es sabido, identifica al pater familias con el único sujeto de Derecho admisible. En palabras de Bercovitz "la idea de que el ser humano es acreedor frente a cualquier ordenamiento del reconocimiento de su condición de persona parece hoy día indiscutible, así como la idea de que ello implica el reconocimiento de unos derechos fundamentales." 92

A toda persona se le reconoce aptitud para ser titular de derechos y obligacio-

con respecto a estas medidas. Para una visión reciente sobre el régimen de la patria potestad en Derecho español, véase: M. A. Torres Mateos, Patria potestad (Pamplona, 2007).

${ }^{87}$ Cfr. artículo 2,I Ley Orgánica $\mathrm{N}^{\circ} 1 / 1996$.

${ }^{88}$ Cfr. artículo 2,II Ley Orgánica $N^{\circ} 1 / 1996$.

${ }^{89}$ Véase: M. Rivera Fernández, Anotaciones a la Ley 1/1996, cit. (n. 89), p. 6504.

${ }^{90}$ Ibíd., p. 6507.

${ }^{91}$ Véase: C. NúNEZZ MuNizZ, Algunas consideraciones sobre la Ley Orgánica 1/1996 de 15 de enero, de Protección jurídica del menor, en La Ley, 4135 (1996), pp. 4 ss.; M. Alonso PéreZ, La situación jurídica del menor en la Ley Orgánica 1/1996, de 15 de enero, de Protección Jurídica del Menor, de modificación del Código Civily de la Ley de Enjuiciamiento Civil: Luces y sombras, en Actualidad Civil, 2 (6-12 de enero de 1997), pp. 30 ss. Esta inmisión del poder público ha sido criticada por la doctrina, en palabras de E. Ramos Chaparro, Presentación de la Ley Orgánica 1/1996, de 15 de enero, en Anuario de Derecho Civil, 49 (1996), p. 678: "No vayamos a convertir al Poder público -que, al fin y al cabo, no procrea aún a los menores- en una rígida y ubicua vigilante institutriz, más paternal que los padres, que, acostumbrada a facultades exorbitantes, dirija por entero la vida del menor".

${ }^{92}$ R. Bercovitz y Rodríguez-Cano, Derecho de la persona (Madrid, 1976), p. 195. En sentido similar, V. L. Montés Penadés, El significado institucional de la idea de persona, en A. LÓPEZ - V. L. Montés (coordinadores), Derecho civil. Parte general ( $2^{a}$ edición, Valencia, 1995), p. 239: "La idea de que todo ser humano es persona, por encima e incluso antes que la colectividad organizada, constituye el eje del Derecho civil y del Derecho en general"; E. Ramos Chaparro, La persona y su capacidad civil (Madrid, 1995), pp. 147 s.: "Así pues, la primacía de la noción real de la persona no es otra cosa que la misma prioridad valorativa que el actual ordenamiento reconoce a la persona humana, al configurar como valores superiores (sic) los mismos atributos ontológicos de aquélla (libertad e igualdad)"; J. M. LETE Del Río, Derecho de la persona (3a edición, Madrid, 1996), p. 22: "Principio fundamental del Derecho moderno es que todo hombre es persona" (sic). 
nes, lo que conocemos como capacidad jurídica, en tanto la capacidad de obrar, como aptitud para actuar válidamente como titular de estos derechos y deberes, es reconocida atendiendo a diversas circunstancias, como la edad ${ }^{93}$. Nuestro Derecho trata incluso de limar las diferencias existentes entre mayores y menores de edad, en un intento por reconocer a éstos el máximo de capacidad, dentro de las limitaciones impuestas por la naturaleza ${ }^{94}$.

Ante estos datos debemos excluir la posible presencia en nuestro ordenamiento civil contemporáneo de una disposición cuyo contenido pudiera asemejarse a la regulación derivada del sc. Macedoniano, pues el necesario presupuesto de una medida de este tipo, la patria potestad de tipo romano clásico, no se da en el Derecho civil español, que recoge un nuevo Derecho de personas y familia muy distinto del romano.

Aun así la doctrina civilista ${ }^{95}$, e incluso algunos romanistas ${ }^{96}$, establecen conexiones entre el sc. M. y el artículo 323 CCEsp., que regula la capacidad de obrar del menor emancipado.

La Ley Orgánica № 1/1996 De protección jurídica del menor, “Disposición final decimoctava”, $\$ 2$, da el siguiente contenido al mencionado artículo ${ }^{97}$ : "[Inciso $1^{\circ}$ L La emancipación habilita al menor para regir su persona y bienes como si fuera mayor, pero hasta que llegue a la mayor edad no podrá el emancipado tomar dinero a préstamo, gravar o enajenar bienes inmuebles y establecimientos mercantiles o industriales u objetos de extraordinario valor sin consentimiento de sus padres, y a falta de ambos, sin el de su curador./ [Inciso $2^{\circ}$ ] El menor emancipado podrá por si solo comparecer en juicio./ [Inciso $3^{\circ}$ [ Lo dispuesto en este artículo es aplicable también al menor que hubiere obtenido judicialmente el beneficio de la mayor edad'.

De aquí deducimos que el menor emancipado, y el habilitado de edad (artículo 323 III), tienen restringida su capacidad de obrar para determinados actos de disposición patrimonial, entre los que se encuentra el tomar dinero a préstamo, lo que, ciertamente, nos trae a la memoria el sc. M. ${ }^{98}$.

${ }^{93}$ Véase: A. Gordillo Cañas, Capacidad, incapacidades y estabilidad de los contratos (Madrid, 1986), pp. 20 ss.; M. a R. VALPUESTA, La capacidady los estados de la persona, en A. LÓPEZ - V. L. Montés (coordinadores), Derecho civil. Parte general (2a edición, Valencia, 1995), pp. 331 ss.; E. Ramos Chaparro, ibíd., pp. 186 ss.; J. M. Lete Del Río, ibíd., pp. 25 ss.

${ }^{94}$ Así la Ley Orgánica N 1/1996, de Protección jurídica del menor, dice en su "Exposición de Motivos", $\$ 2$ : "El desarrollo legislativo postconstitucional refleja esta tendencia, introduciendo la condición de sujeto de derechos a las personas menores de edad. Así el concepto "ser escuchado si tuviere suficiente juicio" se ha ido trasladando a todo el ordenamiento jurídico en todas aquellas cuestiones que le afectan. Este concepto introduce la dimensión del desarrollo evolutivo en el ejercicio directo de sus derechos".

${ }^{95}$ N. Pérez De Castro, El menor emancipado (Madrid, 1988), pp. $162 \mathrm{s.}$

${ }^{96}$ A. Wacke, La prohibición del crédito, cit. (n. 5), p. 181; J. Daza Martínez - L. Rodríguez ENNES, Instituciones de Derecho privado romano (4a edición revisada y ampliada, Valencia, Tirant lo Blanch, 2009), p. 298, en referencia al antiguo artículo 317 CCEsp.

${ }^{97}$ Este artículo había sido ya modificado por la Ley 11/1981, de modificación del Código Civil en materia de filiación, patria potestad y régimen económico del matrimonio, en sustitución del antiguo 317 CCEsp.

${ }^{98}$ Esta limitación a la capacidad de obrar del menor emancipado debe interpretarse de modo restrictivo, pero no por el mandato legal expresado en el artículo 2 de la Ley Orgánica 
Este artículo considera limitado en su capacidad al menor emancipado, sea cual sea la vía por la que ha llegado a la emancipación ${ }^{99}$, para tomar préstamos de dinero, limitación que sólo cesa si el menor cuenta con el consentimiento ${ }^{100}$ de los padres (padre y madre) ${ }^{101}$, de su curador o del cónyuge mayor ${ }^{102}$. Al referirnos a esta restricción que afecta al menor emancipado hemos de tener en cuenta que, en todo caso, la iniciativa del negocio corresponde al menor y que su consentimiento es indispensable, aunque no suficiente, por lo que necesita un complemento. En todo caso, esta incapacidad parcial de disposición no implica limitación alguna en las esferas personal y familiar ${ }^{103}$, ni incapacidad procesal (artículo 323 II).

Por otra parte, estas limitaciones a la capacidad de obrar del menor emancipado no están recogidas en el Proyecto de Código Civil de $1851^{104}$, ni en el "Anteproyecto de 1882-1888”. En cambio, sí aparecen en la primera redacción del

No 1/1996, de cuyo ámbito de aplicación queda excluido, sino en aplicación del criterio general establecido para las limitaciones a la capacidad de obrar de cualquier persona. Véase: A. Gullón Ballesteros, Sobre la Ley 1/1996, de Protección Jurídica del Menor, en La Ley, 3970 (1996), p. 2. Para M. Alonso Pérez, La situación jurídica del menor, cit. (n. 98), p. 39. En cambio, para M. ${ }^{a}$ R. Valpuesta, Los estados civiles I, en A. López-V. L. Montes (coordinador), Derecho civil. Parte general (2a edición, Valencia, 1995), p. 380, estas limitaciones no deben interpretarse de modo restrictivo, pues, aunque la regla general sea el reconocimiento de la capacidad de obrar para el menor emancipado, se refieren a "actos que pueden tener gran trascendencia desde el punto de vista jurídico y económico".

${ }^{99} \mathrm{El}$ artículo 324 CCEsp. , que regula condiciones especiales para el menor emancipado casado, no modifica el tenor de lo dispuesto en el 323 CCEsp. en relación con la toma de dinero a préstamo. Véase: N. Pérez de CASTro, El menor emancipado cit. (n. 95), pp. 174 ss. Hay que tener en cuenta, en este punto, que el artículo 4 de la Compilación de Derecho Civil de Aragón, aplicable de acuerdo con la "Disposición adicional segunda" CPolEsp., prescribe que tendrán la consideración de mayores de edad los menores desde el momento en que contraen matrimonio, por lo que a éstos no les afecta el contenido del artículo 323 CCEsp. Véase: J.

M. Lete Del Río, Derecho de la persona, cit. (n. 92), p. 67.

${ }^{100}$ Para L. Puig Ferrol, Artículo 323, en Comentario del Código Civil (Madrid, 1993), I, p. 885 , el consentimiento lo presta el menor emancipado, lo que realmente requiere este artículo es un asentimiento complementario de las personas en él mencionadas, lo que no llega a que el menor sea suplantado por su representante legal. En el mismo sentido, R. BERCOVITZ y Rodríguez-CANo, Derecho de la persona, cit. (n. 92), p. 43, en referencia al antiguo artículo 317; N. Pérez de Castro, EL menor emancipado, cit. (n. 95), p. 150.

${ }^{101}$ En opinión de A. Rodríguez AdRados, Reforma del Código Civil en materia de emancipación, en Revista de Derecho Notarial, 111 (1981) p. 358, el consentimiento ha de prestarse por el padre y la madre conjuntamente, a diferencia de lo dispuesto por el antiguo artículo 317. Para M. a Del Carmen Gete-Alonso y Calera, La nueva normativa en materia de capacidad de la persona (2a edición, Madrid, 1992), pp. 134: “[...] sólo será válida la intervención de uno de los padres cuando el otro no exista (física ni jurídicamente) o se halle privado totalmente de la patria potestad."

${ }^{102}$ Cfr. artículo 324 CCEsp. Véase: E. Ramos Chaparro, La persona y su capacidad civil, cit. (n. 92), p. 393.

${ }^{103}$ L. Puig Ferrol, Artículo 323, cit. (n. 100), p. 884.

${ }^{104}$ F. García Goyena, Concordancias, motivos y comentarios del Código Civil español (Reimpresión de la edición Madrid, 1852, Zaragoza, 1974), pp. 152 ss., critica la existencia de estas restricciones a la capacidad del menor emancipado. 
Código en 1888 (artículo 317), añadiéndose a estas restricciones la imposibilidad de comparecer en juicio por sí solo ${ }^{105}$.

También encontramos una restricción en el mismo sentido en la ley $\mathrm{N}^{\circ} 66$ de la Compilación del Derecho Civil Foral de Navarra, si bien ésta sólo requiere el consentimiento del padre o de la madre o de los parientes mayores.

El Derecho civil francés, a menudo referente de los codificadores españoles, recogía en los arts. 480 a 484 del Code una serie de limitaciones a la capacidad de obrar del menor emancipado entre las que se encontraba el tomar dinero a préstamo, empero, estas limitaciones fueron sustituidas en 1964 por una restricción genérica en el ejercicio del comercio ${ }^{106}$.

Entrando en materia, es decir, en la comparación del sc. M. y la medida civil que analizamos, cabe afirmar que la limitación contenida en el Código civil tiene en común con el sc. M. su concreción a los préstamos de dinero; no se impide que el menor emancipado sea prestatario si el objeto del negocio es distinto del dinero $^{107}$, como tampoco nuestro sc. incidía en los negocios distintos del mutuo en que era parte el filius familias. Además, dicha restricción a la capacidad de obrar del menor emancipado cesa si concurre el asentimiento de los padres, del curador o del cónyuge mayor y, recordemos, que la presencia del consentimiento paterno en el régimen del sc. M. suponía una derogación parcial del mismo.

Las dos anteriores serían las que, en sentido amplio, podríamos llamar similitudes entre el senatus consultum Macedonianum y el artículo 323 CCEsp. Pero, aunque existan aspectos en que sc. M. y el precepto civil de referencia "se toquen", existen otros muchos en los que uno y otro difieren abiertamente. A poner de manifiesto estas diferencias nos disponemos a continuación:

En primer lugar, la situación de un emancipado en Derecho romano es la de un sui iuris; el hecho de haber llegado a este status por un camino diferente del que supone la muerte o capitis deminutio de su padre no conlleva limitación alguna en sus facultades de disposición, como vemos que sí ocurre respecto al emancipado que regula el Derecho vigente.

En segundo lugar, el artículo 323 contiene una limitación directa al menor emancipado, lo que requiere un complemento de capacidad para determinados negocios que, de llevarse a cabo sin la concurrencia del asentimiento de un tercero, son considerados nulos ${ }^{108}$; como sabemos, el hijo de familia que es parte en

${ }^{105}$ Véase: N. Pérez De Castro, El menor emancipado, cit. (n. 95), pp. 165 s.

${ }^{106}$ Artículo 487 Code civil fr.: "Le mineur émancipé ne peut être commerçant."

${ }^{107}$ Para L. Puig Ferrol, Artículo 323 cit. (n. 100), p. 885: “[...] la limitación deberá hacerse extensiva a cualquier otro negocio jurídico, cuya finalidad económica coincida con la del préstamo dinerario", véase: al respecto J. M. LeTE Del Río, Derecho de la persona cit. (n. 92), p. 84. En este sentido, la regulación vigente también coincide con el sc. M., ya que éste no queda derogado cuando se trata de defraudar su contenido ocultando el mutuo bajo otra forma negocial.

${ }^{108}$ Sobre este extremo y sobre la relación del 323 y 1824 CCEsp., véase: N. PÉREZ DE Castro, El menor emancipado, cit. (n. 95), pp. 178 ss.; L. Díez-Picazo - A. Gullón, Sistema de Derecho civil (6a edición, Madrid 1988), I, pp. 250 s. Este último extremo es digno de un estudio ulterior, también desde la perspectiva crítica que ofrece la atalaya del Derecho romano. 
un mutuo contrae una obligación civil perfectamente válida, aunque ésta quede después desprotegida procesalmente por efecto del sc. M.

$\mathrm{Y}$ en tercer lugar, las dos disposiciones que comparamos se separan en los objetivos a que se dirigen. Para Pérez de Castro, el contenido del actual artículo 323 CCEsp. se encuadra en la lucha contra la usura que hunde sus raíces en nuestro Derecho histórico y que tiene exponentes tan conocidos como la Ley de 23 de julio de 1908 o "Ley Azcárate" 109 . A nosotros nos parece más una medida de protección de los menores emancipados, a los que se trata de amparar dada su bisoñez, véase en este sentido como todos los actos para los que este artículo requiere un consentimiento añadido dan lugar a negocios que pueden acarrear nefastas consecuencias para el menor emancipado, si bien con respecto a estos negocios y su peligrosidad podemos decir que "son todos los que están, pero no están todos los que son" ${ }^{110}$.

En definitiva, lo que, en cualquier caso, excluimos es que estemos ante una medida con el mismo objetivo que el sc. M., que se dirige a salvaguardar la patria potestad $^{111}$.

\section{CONCLusiones}

Tras el análisis precedente, hemos llegado a las siguientes conclusiones:

En primer lugar, excluimos, ahora fundadamente, un traslado del sc. M. a nuestro Derecho civil, ya hagamos referencia al ordenamiento histórico o al contemporáneo; esto se debe a que en nuestro Derecho patrio ha desaparecido la patria potestas de corte romano, objetivo amparado por el senatus consultum Macedonianum.

En segundo lugar, en Derecho histórico español hallamos algunos preceptos que nos recuerdan al sc. M.; pero, aunque en unos casos las similitudes con éste son mayores que en otros, estimamos que la relación entre la medida romana y las castellanas no pasa de ser un recuerdo en la mente del investigador, no un antecedente.

Y, en tercer lugar, pensamos que el artículo 323 CCEsp. dista mucho de ser una derivación del sc. M. y que sólo estamos ante una reminiscencia, pues quizá lo único que vincula una y otra medida es la conciencia sobre la peligrosidad que acarrea el endeudamiento. En cualquier caso, no podemos soslayar en este caso el peso de la tradición histórica proveniente del Derecho romano, ya que los codificadores eligen precisamente el préstamo de dinero entre los múltiples negocios que pueden acarrear importantes responsabilidades a los menores emancipados, lo que sólo se explica atendiendo a la importancia de la inercia histórica.

${ }^{109}$ N. Pérez De Castro, El menor emancipado, cit. (n. 95), pp. 166 ss.

${ }^{110}$ En este sentido, véase: R. Bercovitz y Rodríguez-Cano, Derecho de la persona, cit. (n. 92), en referencia al antiguo artículo $317 \mathrm{CCE}$

${ }^{111}$ Ninguna opción dentro de la doctrina civilista se inclina a atribuir este objetivo al artículo 323 CCEsp.; ibíd., pp. 170 s. 


\section{BiBLIOGRAFÍA}

Alejandre García, Juan Antonio, Temas de Historia del Derecho: Derecho primitivo y romanización jurídica (Sevilla, 1981).

Alonso Pérez, Mariano, La situación jurídica del menor en la Ley Orgánica 1/1996, de 15 de enero, de Protección Jurídica del Menor, de modificación del Código Civil $y$ de la Ley de Enjuiciamiento Civil: Luces y sombras, en Actualidad Civil, 2 (6-12 de enero de 1997).

Bercovitz y Rodríguez-Cano, Rodrigo, Derecho de la persona (Madrid, 1976).

Coderch Manau, Salvador - Coderch Mir, S., Tratado de la menor edad. Estudio de la situación legal del menor mientras está sujeto a patria potestad y a tutela, cuando ha obtenido su emancipación y al llegar a la mayor edad, asi como de los derechos y deberes de sus padres, de su Consejo de familia, de su tutor y de su protutor (Barcelona 1917).

D'ORs, Álvaro, Escritos varios sobre el Derecho en crisis (Roma - Madrid, 1973).

Daza Martínez, Jesús - Rodríguez Ennes, Luis, Instituciones de Derecho privado romano ( $4^{\mathrm{a}}$ edición revisada y ampliada, Valencia, Tirant lo Blanch, 2009).

De La TORRE, Ángel (editor), La reconquista española y la repoblación del país (Zaragoza, 1951).

Díez-Picazo, Luis - Gullón, Antonio, Sistema de Derecho civil (6a edición, Madrid 1988), I.

Díez-PiCAZo, Luis, El Derecho de la persona y el Derecho de familia en la Legislación de 1870, en Estudios de Derecho privado (Madrid 1980).

Díez-PiCAzo, Luis, Notas sobre la reforma del Código civil en materia de patria potestad, en Anuario de Derecho Civil, 25 (1982) 1.

Gacto Fernández, E. - Alejandre García, J. A. - García Marín, J. M., El Derecho histórico de los pueblos de España (5a edición, Madrid, 1985).

García AtAnce, Manuel de, "De consuetudine Regni non habemus patriam potestatem", en $A D A$., 6 (1951-1952).

García De Valdeavellano, Luis, La comunidad patrimonial de la familia en el Derecho español medieval (Salamanca, 1956).

GarCÍA GoYena, Florencio, Concordancias, motivos y comentarios del Código Civil español (Reimpresión de la edición Madrid, 1852, Zaragoza, 1974).

García-Gallo, Alfonso, Manual de Historia del Derecho español, I: El origen y la evolución del Derecho (6a edición revisada, Madrid, 1975).

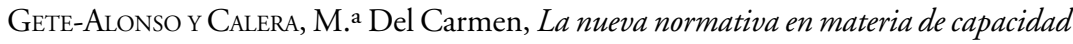
de la persona (2a edición, Madrid, 1992).

Gordillo Cañas, Antonio, Capacidad, incapacidades y estabilidad de los contratos (Madrid, 1986).

Gullón Ballesteros, Antonio, Sobre la Ley 1/1996, de Protección Jurídica del Menor, en La Ley, 3970 (1996).

LALINDE ABADÍA, Jesús, Introducción histórica al Derecho español, (4a edición reformada, Barcelona, 1989).

Lalinde Abadía, Jesús, Derecho histórico español (3a edición, Barcelona, 1983).

Lete Del Río, José Manuel, Derecho de la persona (3a edición, Madrid, 1996).

Linacero de la Fuente, María Asunción, Régimen patrimonial de la patria potestad (Madrid, 1990). 
LÓPEZ PÉREZ, Jerónimo, La patria potestad, Voluntad del titular ("Prólogo" de I. Serrano y Serrano, Valladolid, 1982).

Martínez Gijón, José, La familia del Fuero de Cuenca. Estado de una investigación científica, en Atti del II Congresso Internazionale della Società Italiana di Storia del Diritto (Firenze, 1971).

Martínez Gijón, José, Los sistemas de tutela y administración de los bienes de los menores en el Derecho local de Navarra, en AHDE., 40 (1970).

Martínez Gijón, José, Los sistemas de tutela y administración de los bienes de los menores en el Derecho local de Castilla y León, en AHDE., 41 (1971).

Merchán Álvarez, Antonio, La tutela de los menores en Castilla hasta fines del siglo $X V$ (Sevilla, 1976).

MerÊA, Paulo, Notas sobre o poder paternal no Dereito hispânico ocidental, en AHDE., 18 (1947) [= Estudos de Dereito hispânico medieval (Coimbra, 1953), II].

Montanos Ferrín, Emma, La familia en la Alta Edad Media española (Pamplona, 1980).

Montés Penadés, Vicente Luis, El significado institucional de la idea de persona, en A. LÓPEZ - V. L. MONTÉs (coordinadores), Derecho civil. Parte general (2a edición, Valencia, 1995).

NúÑEz MuñIZ, Carmen, Algunas consideraciones sobre la Ley Orgánica 1/1996 de 15 de enero, de Protección jurídica del menor, en La Ley, 4135 (1996).

Otero Varela, Alfonso, La patria potestad en el Derecho histórico español, en AHDE., 26 (1956).

Paricio, Javier, recensión a F. Lucrezi, Senatusconsultum Macedonianum (Napoli, 1992), en Ivra, 43 (1992).

Paricio, Javier - Fernández Barreiro, Alejandrino, Historia del Derecho romano y su Recepción europea, (2a edición, Madrid, 1997).

Pérez de Castro, Nazareth, El menor emancipado (Madrid, 1988).

Periñán Gómez, Bernardo, Antecedentes y consecuencias del sc. Macedoniano (Valencia, 2000).

Puig Ferrol, Luis, Artículo 323, en Comentario del Código Civil (Madrid, 1993), I.

Ramos Chaparro, Enrique, Niños y jóvenes en el Derecho civil constitucional, en Derecho Privado y Constitución, 7 (1995).

Ramos Chaparro, Enrique, Presentación de la Ley Orgánica 1/1996, de 15 de enero, en Anuario de Derecho Civil, 49 (1996).

Ramos Chaparro, Enrique, La persona y su capacidad civil (Madrid, 1995).

Rivera Fernández, Manuel, Anotaciones a la Ley 1/1996, de 15 de enero, de protección jurídica al menor, en Revista General de Derecho, 621 (junio 1996).

Rodríguez Adrados, Antonio, Reforma del Código Civil en materia de emancipación, en Revista de Derecho Notarial, 111 (1981).

Rodríguez Montero, Ramón, La "casa” en Galicia. Notas características y apuntes históricos sobre la regulación normativa de su indivisibilidad, en B. PERIŃÁN GÓMEZ (coordinador), Derecho, persona y ciudadaní. Una experiencia jurídica comparada (Madrid - Barcelona - Buenos Aires, 2010).

SÁnCHEZ-Albornoz, Claudio, España, un enigma histórico (8a edición, Barcelona 1981).

Tomás y Valiente, Francisco, Manual de Historia del Derecho español (4a edición, Madrid, 1983).

Torrent Ruiz, Armando, El Derecho romano como instrumento para la crítica del 
Derecho positivo, en VV. AA., Homenaje a Juan Berchmans Vallet de Goytisolo (Madrid, 1988), I.

Torres Mateos, Miguel Ángel, Patria potestad (Pamplona, 2007).

Valpuesta, María Rosario, Los estados civiles, I, en A. López-V. L. Montes (coordinador), Derecho civil. Parte general (2a edición, Valencia, 1995).

Valpuesta, María Rosario, La capacidad y los estados de la persona, en A. López - V. L. Montés (coordinadores), Derecho civil. Parte general (2a edición, Valencia, 1995).

Ventoso Escribano, Alfonso, La representación y disposición de los bienes de los hijos (Madrid, 1989).

WaCKe, Andreas, Das Verbot der darlehnsgewährung an Hauskinder und die Gebote wirtschaflicher vernunft, en ZSS., 112 (1995).

WACKE, Andreas, La prohibición del crédito para los hijos de familia y el dictado de la razón económica, en Seminarios Complutenses de Derecho Romano, 6 (1994). 